\title{
PENGARUH PENERAPAN MODEL PEMBELAJARAN PAIR CHECK TERHADAP KEMAMPUAN NUMERIK SISWA KELAS VII SMP NEGERI 3 GIANYAR
}

\author{
A.E.T. Melani, I.M. Candiasa, I.G.N.Y. Hartawan \\ Program Studi Pendidikan Matematika Universitas Pendidikan Ganesha \\ Singaraja, Indonesia \\ e-mail: emelan.melani@yahoo.com , candiasamade@gmail.com , \\ hartawan.math@gmail.com
}

\begin{abstract}
Abstrak
Penelitian ini bertujuan untuk mengkaji pengaruh model pembelajaran Pair Check terhadap kemampuan numerik siswa. Jenis penelitian ini adalah eksperimen semu dengan post-test only control group design. Populasi penelitian ini adalah siswa kelas VII SMP Negeri 3 Gianyar tahun ajaran 2017/2018 yang berjumlah 383 orang siswa dan tersebar dalam 10 kelas. Sampel ditentukan dengan teknik cluster random sampling setelah dilakukan uji kesetaraan kelas menggunakan uji ANAVA. Kelas VII B yang terpilih sebagai kelompok eksperimen dan kelas VII A sebagai kelompok kontrol. Data kemampuan numerik siswa diperoleh melalui tes obyektif. Data dianalisis menggunakan uji $U$ Mann-Whitney. Berdasarkan hasil pengujian dengan uji $U$ Mann-Whitney, diperoleh rata-rata peringkat untuk siswa kelompok eksperimen adalah 43,62 dan rata-rata peringkat kelompok kontrol adalah 33,38. Nilai $U$ sebesar 527,500 dengan $p$ value $=0,0188$ dan $\alpha=0,05$ jadi $p$ value $<\alpha$ yang berarti $\mathrm{H}_{0}$ ditolak dan menunjukkan bahwa kemampuan numerik siswa kelas VII SMP Negeri 3 Gianyar yang dibelajarkan dengan model pembelajaran pair check lebih tinggi daripada siswa yang dibelajarkan dengan pembelajaran konvensional. Dengan demikian dapat disimpulkan bahwa model pembelajaran pair check berpengaruh positif terhadap kemampuan numerik siswa
\end{abstract}

Kata Kunci: Model pembelajaran pair check, kemampuan numerik.

\begin{abstract}
This research aimed to determine the influence of pair check learning model towards the numerical ability. This type of the research was a quasi-experiment with post-test only control group design. The population of this study was $7^{\text {th }}$ grade students of SMP Negeri 3 Gianyar academic year 2017/2018 which amounts to 383 students and divided into 10 classes. The sample of this study was chosen by using cluster random sampling technique after implementing the equality by using ANOVA test. $7^{\text {th }}$ grader of $B$ class as experimental group and $7^{\text {th }}$ grader of A class as control group. Data on students' numerical ability was obtained through an objective test. The data were analyzed by using $U$ Mann Whitney test. Based on the data analysis, the mean rank of students' numerical ability of the experimental group was 43,62 and the control group' was 33,38. U value was 527,500 with $p$ value $=$ 0,0188 and $\alpha=0,05$ so $p$ value $<\alpha$ which means $H_{0}$ was rejected and it shows that the numerical ability of $7^{\text {th }}$ grader students of SMP Negeri 3 Gianyar which is taught by pair check learning models higher than students who is taught by conventional learning. It can be concluded that the pair check learning models has a positive effect on students' numerical ability
\end{abstract}

Keywords: pair check learning models, numerical ability. 


\section{PENDAHULUAN}

Pembukaan

UUD

1945

mengamanatkan bahwa tujuan pendidikan nasional bangsa Indonesia adalah mencerdaskan kehidupan bangsa melalui pemerataan pendidikan bagi setiap warga Negara. Melalui pendidikan diharapkan terbentuk tunas-tunas bangsa yang cerdas, berjiwa kebangsaan, cinta tanah air, bertanggung jawab, serta peka terhadap kondisi sosial dan lingkungan. Dengan kata lain, pendidikan mempunyai kewajiban untuk membentuk sumber daya manusia (SDM) yang berkualitas. Indonesia merupakan salah satu negara yang dianggap sebagai ekonomi awal dan berkembang menurut laporan Ekonomi Dunia Dana Moneter Internasional pada bulan April 2017. Sebagai negara yang masih berkembang, Indonesia melakukan pembangunan sebagai proses yang berkesinambungan yang mencakup seluruh aspek kehidupan masyarakat, termasuk aspek sosial, ekonomi, politik dan kultural. Dalam proses pembangunan, peran pendidikan sangat penting karena bertugas menyiapkan sumber daya manusia untuk pembangunan. Pendidikan mampu menciptakan sumber daya manusia yang berkualitas dan dapat membangun perekonomian negera ini.

Pendidikan merupakan investasi jangka panjang yang sangat penting dalam menghadapi tantangan zaman di masa depan karena dengan pendidikan mampu menyiapkan generasi muda abad ke-21 yang unggul dan berdaya saing tinggi. Oleh karena itu, negara sangat memperhatikan pemerataan pendidikan kepada warganya seperti tercantum pada Pembukaan Undang-Undang Dasar Negara Republik Indonesia pasal 31 ayat 1 yang menyebutkan bahwa, "Setiap warga negara berhak mendapatkan pendidikan". Pemerataan pendidikan tanpa membedakn suku, agama, ras ini diharapkan mampu menyiapkan generasi muda yang unggul di setiap daerah di Indonesia yang siap kembali untuk membangun daerahnya demi tercapainya pembangunan di negara Indonesia secara merata. Pembangunan yang bergerak maju menunjukkan adanya keberhasilan dari pendidikan yang diselenggarakan oleh pemerintah. Qomar (2012:15) menyatakan,

Terdapat beberapa faktor penentu keberhasilan dalam meningkatkan kualitas pendidikan antara lain: proses, tujuan, visi misi, kurikulum, metode, alat, saranaprasarana, lingkungan, iklim akademik, proses pembelajaran, pimpinan, pendidik dan siswa.

Kurikulum mencakup beberapa mata pelajaran, salah satunya adalah matematika. Matematika memiliki peranan penting dalam berbagai aspek kehidupan. Banyak permasalahan dan kegiatan dalam hidup kita yang harus diselesaikan dengan menggunakan ilmu matematika seperti menghitung, mengukur, dan lain-lain. Matematika merupakan salah satu dari bidang studi yang memegang peranan sangat penting dalam dunia pendidikan. Para pelajar memerlukan matematika untuk memenuhi kebutuhan praktis dan memecahkan masalah dalam kehidupan sehari-hari (Suherman, 2003). Selain itu, matematika dalam pelaksanaan pendidikan diberikan di semua jenjang pendidikan dari SD sampai SMA. Dewasa ini, matematika justru merupakan salah satu mata pelajaran yang cenderung meresahkan sekaligus membosankan bagi siswa. Sistem pengajaran yang diterapkan di kelas memegang peranan yang sangat sentral di dalam mempengaruhi minat dan motivasi belajar siswa.

Jika berbicara mengenai prestasi matematika Indonesia dikancah internasional, seperti dilansir oleh hasil survei Programme International for Student Assesment atau PISA pada tahun 2015 (Organisation for Economic Cooperation and Development atau OECD, 2016) menunjukkan bahwa kemampuan matematika siswa Indonesia menempati ranking 63 dari 70 negara dengan skor ratarata 386, sedangkan skor rata-rata internasional adalah 490. Selain itu, juga dapat dilihat dari nilai rata-rata Ujian Nasional (UN) matematika tingkat SMP seProvinsi Bali. Terjadi penurunan rata-rata nilai UN Matematika dari tahun ke tahun. Pada tahun ajaran 2015/2016 rata-ratanya 
sebesar 46,55 sedangkan pada tahun ajaran 2016/2017 sebesar 43,63.

Penurunan ini mengindikasikan bahwa nilai matematika yang diperoleh siswa masih rendah. Banyak faktor penyebab terjadinya penurunan nilai matematika salah satunya menurut Mamik Suratmi (dalam Jayantika, 2013) menemukan siswa belum memiliki kemampuan dasar yang baik salah satunya yaitu kemampuan numerik sehingga menyebabkan siswa kesulitan dalam menjawab soal-soal yang menuntut kemampuan numerik yang baik dalam menyelesaikannya. Berbagai upaya untuk meningkatkan kualitas pembelajaran matematika telah banyak dilakukan, baik oleh pemerintah maupun oleh berbagai pihak yang peduli terhadap pembelajaran matematika di sekolah. Berbagai upaya tersebut antara lain dalam bentuk: (1) penataan guru, (2) kualifikasi pendidikan guru, (3) pembaharuan kurikulum, (4) implementasi model atau metode pembelajaran baru, (5) penelitian tentang kesulitan dan kesalahan siswa dalam belajar matematika. Namun berbagai upaya tersebut belum mencapai hasil yang optimal karena berbagai kendala. Hal ini bisa dilihat pada proses pembelajaran matematika di sekolah yaitu siswa tidak memahami materi yang diajarkan. Akibatnya siswa tidak bisa menyelesaikan soal-soal yang diberikan oleh guru. Penyebab hal tersebut terjadi karena adanya faktor internal yang berasal dari dalam diri siswa. Salah satu faktor internal adalah kemampuan numerik.

Selaras dengan itu Trisna Jayantika (2013) menemukan rendahnya kemampuan numerik siswa merupakan salah satu faktor penyebab kesulitan belajar Matematika. Bakat numerik merupakan salah satu faktor internal yang mempengaruhi pencapaian prestasi belajar siswa. Menurut Irawan (2014) kemampuan numerik adalah kemampuan dalam menggunakan angkaangka dan penalaran (logika) meliputi bidang matematika, mengklasifikasikan dan mengkategorikan informasi, berpikir dengan konsep abstrak untuk menemukan hubungan antara suatu hal dengan hal lainnya. Sedangkan, menurut Slametto (2007) kemampuan numerik mencakup kemampuan standar tentang bilangan, kemampuan berhitung yang mengandung penalaran dan keterampilan aljabar, kemampuan mengoperasikan bilangan meliputi operasi hitung penjumlahan, pengurangan, perkalian, dan pembagian. Berdasarkan pernyataan di atas dapat disimpulkan bahwa kemampuan menghitung (kemampuan numerik) merupakan potensi alamiah yang dimiliki seseorang dalam bidang matematika.

Kemampuan numerik merupakan salah satu bagian operasi menghitung dalam matematika dan sangat dibutuhkan dalam menyelesaikan persoalan-persoalan matematika. Kesulitan yang dialami siswa bukan hanya memahami materi yang diajarkan tetapi masih banyak siswa yang bingung dan melakukan kesalahan dalam melakukan perhitungan yang sederhana.

Kemampuan numerik sangat membantu siswa dalam memahami materi, menganalisis setiap permasalahan, dan menerapkan konsep matematika dalam kehidupan sehari-hari serta siswa tidak mengalami kesulitan dalam belajar. Dalam penguasaan keterampilan numerik, pada dasarnya siswa dituntut untuk melakukan prosedur dan operasi yang cepat dan benar, serta mencoba latihan-latihan yang cukup untuk menguatkan kemampuan numeriknya. Latihan-latihan yang diberikan kepada siswa dalam bentuk LKS (Lembar Kerja Siswa). Salah satu model pembelajaran yang akan diterapkan adalah dengan model pembelajaran Pair Check.

Salah satu model pembelajaran yang melibatkan siswa adalah model pembelajaran kooperatif tipe Pair Check. Pada model pembelajaran kooperatif tipe Pair Check ini siswa dibagi dalam kelompokkelompok dan satu kelompok terdiri terdiri dari dua orang saja. Kepada tiap kelompok siswa diberi suatu masalah. Mereka harus berusaha untuk menyelesaikan suatu masalah tersebut, kemudian hasil diskusi kelompok mereka akan dicek oleh pasangan dari kelompok lain. Karena hanya terdiri dari dua orang, pasangan ini akan belajar dengan lebih aktif dalam memecahkan masalah dan mempero $ᄀ$ leh pengetahuan baru. Model pembelajaran kooperatif tipe Pair Check ini merupakan salah satu cara untuk membantu siswa yang pasif dalam kegiatan kelompok, mereka melakukan kerja sama secara berpasangan dan menerapkan 
susunan pengecekan berpasangan (Danasasmita, 2008).

Model pembelajaran Pair Check melatih tanggung jawab sosial siswa, kerja sama, dan kemampuan memberi penilaian (Huda, 2013). Kemampuan memberi penilaian merupakan bagian dari taksonomi kognitif yang dikemukakan oleh Anderson sebagai revisi dari taksonomi Bloom. Pada tahapan-tahapan dari pembelajaran Pair Check dapat membantu siswa dalam membangkitkan rasa percaya diri terhadap kemampuan numerik dalam memecahkan soal. Contohnya pada tahap pair work (bekerja berpasangan), siswa yang berperan sebagai pemecah masalah menjawab soal-soal yang terdapat dalam LKS sebagai kesempatan dalam menerapkan aspek kemampuan numerik dalam hal berhitung. Penerapan kemampuan mengaplikasikan hitung menghitung ini diartikan sebagai kesanggupan siswa untuk menerapkan atau menggunakan ide-ide umum, tata cara atau metode, prinsip-prinsip, rumus-rumus, teoriteori dan sebagainya dalam situasi yang baru dan konkret (Sudijono, 2009). Disamping itu, pada tahapan coach check (pelatih mengecek) dan tahapan pair check (pasangan mengecek), memberikan kesempatan kepada siswa untuk menilai pekerja pasangannya dan pasangan lainnya. Dalam pemeriksaan tersebut, siswa dituntut untuk mengecek dan mengkritisi pekerjaan pasangannya dengan berpikir kritis, penalaran, aspek ketepatan dan ketelitian yang mampu mengoptimalkan kemampuan numerik siswa.

Pembagian kelompok siswa secara berpasangan menunjukkan pencapaiาan yang jauh lebih besar dalam bidang ilmu pengetahuan dari pada kelompok yang terdiri atas empat atau lima orang (Slavin, 2010). Berdasarkan hasil penelitian yang dilakukan oleh I Made Adi Wirayana (2015) dengan menerapkan model pembelajaran pair check menunjukkan bahwa dengan pembagian kelompok siswa secara berpasangan dan berbantuan kartu soal menunjukkan bahwa model pembelajaran kooperatif tipe pair check berbantuan kartu soal berpengaruh positif terhadap hasil belajar matematika siswa. Selain itu, penelitian yang dilakukan oleh $\mathrm{Ni} \mathrm{Md}$.
Yantini, dkk (2012) juga menunjukkan bahwa model pembelajaran kooperatif tipe pair check dapat meningkatkan hasil belajar materi bangun ruang dan bangun datar pada siswa.

Sehubungan dengan pemaparan di atas, peneliti memandang perlu untuk mendapat bukti empiris yang lebih reliabel tentang Pengaruh Penerapan Model Pembelajaran Pair Check Terhadap Kemampuan Numerik Siswa Kelas VII SMP Negeri 3 Gianyar karena diduga model pembelajaran pair check mempunyai pengaruh terhadap kemampuan numerik siswa SMP.

\section{METODE}

Penelitian ini merupakan eksperimen semu (quasi experiment) dengan desain penelitian yang digunakan adalah "post test only control group design" dengan instrumen yang digunakan yaitu tes obyektif untuk mengukur kemampuan numerik siswa.

Populasi dalam penelitian ini adalah seluruh siswa kelas VII SMP Negeri 3 Gianyar Tahun Ajaran 2017/2018 yang terbagi ke dalam 10 kelas dengan total jumlah siswa adalah 383 orang.

Teknik pengambilan sampel dalam peneltian ini dilakukan dengan teknik cluster random sampling, yaitu pengambilan sampel secara random dimana populasi dibagi menjadi beberapa cluster dan masing-masing cluster merupakan kelompok individu yang homogen. Sebelum pengambilan sampel, dilakukan pengujian kesetaraan dengan menggunakan uji anava satu jalur. Uji kesetaraan ini dilakukan untuk memperlihatkan bahwa populasi yang digunakan setara. Data yang digunakan dalam melakukan uji kesetaraan ini adalah nilai ulangan akhir matematika siswa kelas VII semester ganjil tahun pelajaran 2017/2018.

Penelitian ini bertujuan untuk menyelidiki pengaruh variabel bebas (independent variable) terhadap variabel terikat (dependent variable). Adapun variabel bebas dalam penelitian ini adalah model pembelajaran pair check sedangkan variabel terikatnya adalah kemampuan numerik siswa.

Sebelum dilaksanakan uji coba tes kemampuan numerik siswa, pengujian 
validitas isi dilakukan oleh dosen ahli. Hasil validitas isi menunjukkan bahwa tes kemampuan numerik siswa layak untuk digunakan. Setelah melakukan uji pakar, maka dilakukan uji coba tes kemampuan numerik untuk menguji validitas dan reliabilitas tes.

Hasil dari ujicoba menunjukkan bahwa tes kemampuan numerik yang terdiri dari 30 soal dinyatakan valid. Tes tersebut kemudian diuji reliabitasnya dan diperoleh reliabitas tes kemampuan numerik siswa sebesar 0.923 yang tergolong dalam kategori sangat tinggi.

Sebelum dilakukan pengujian hipotesis, data yang diperoleh harus memenuhi uji prasyarat sebagai berikut;

1) Uji normalitas untuk skor kemampuan numerik menggunakan uji Liliefors. Pada pengujian normalitas dengan menggunakan uji Liliefors, dicari selisih antara frekuensi sebaran data dengan frekuensi kumulatif sampai batas tiap-tiap data,

2) Uji homogenitas varians untuk kedua kelompok dengan menggunakan uji Levene. Uji Levene dilakukan dengan mencari selisih masingmasing skor dengan rata-rata datanya kemudian membandingkan hasilnya dengan nilai $F$ tabel.

Pada uji normalitas diperoleh hasil tidak normal, sehingga uji hipotesis menggunakan uji U-Mann Whitney. Hipotesis dalam penelitian ini berbunyi kemampuan numerik siswa kelas VII SMP Negeri 3 Gianyar yang mengikuti pembelajaran dengan model pembelajaran pair check lebih tinggi daripada siswa yang mengikuti pembelajaran konvensional.

\section{HASIL DAN PEMBAHASAN Hasil Penelitian}

Data hasil penelitian mengenai kemampuan numerik siswa yang diperoleh dari post-test yang diberikan pada kelompok eksperimen dan kelompok kontrol dapat dilihat pada tabel berikut.

Tabel 1. Rangkuman Analisis Data Kemampuan Numerik Siswa

Variabel Kelompok

\begin{tabular}{ccc}
\hline & Eksperimen & Kontrol \\
\hline $\mathrm{n}$ & 38 & 38 \\
\hline$\overline{\bar{Y}}$ & 24,9737 & 23,9737 \\
\hline $\mathrm{S}$ & 1,5852 & 3,2507 \\
\hline
\end{tabular}

Keterangan:

$\mathrm{n} \quad$ : banyak siswa

$\bar{Y} \quad$ : rata-rata skor kemampuan numerik siswa

S : simpangan baku

Berdasarkan Tabel 2 hasil perhitungan skor tes kemampuan numerik siswa menunjukkan bahwa rata-rata skor siswa kelompok eksperimen lebih tinggi dari rata-rata skor kemampuan numerik siswa kelompok kontrol.

Penyebaran data kelompok eksperimen yang ditampilkan dalam boxplot pada Gambar 1 menunjukkan tidak simetris dan condong ke arah kiri.

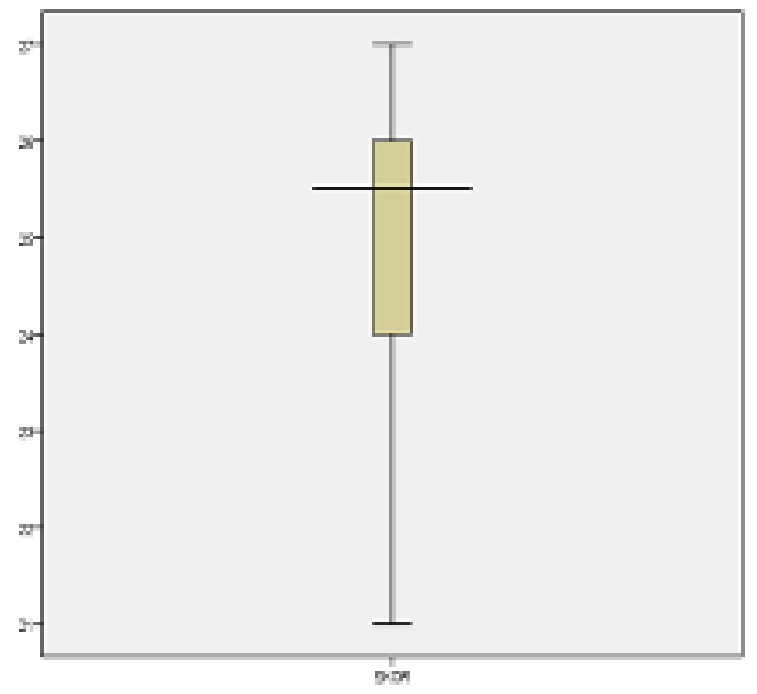

Gambar 1. Penyebaran data kelompok eksperimen

Pada Gambar 2 yang menampilkan boxplot penyebaran data pada kelompok kontrol menunjukkan penyebaran yang tidak simetris dan terdapat data pencilan. 


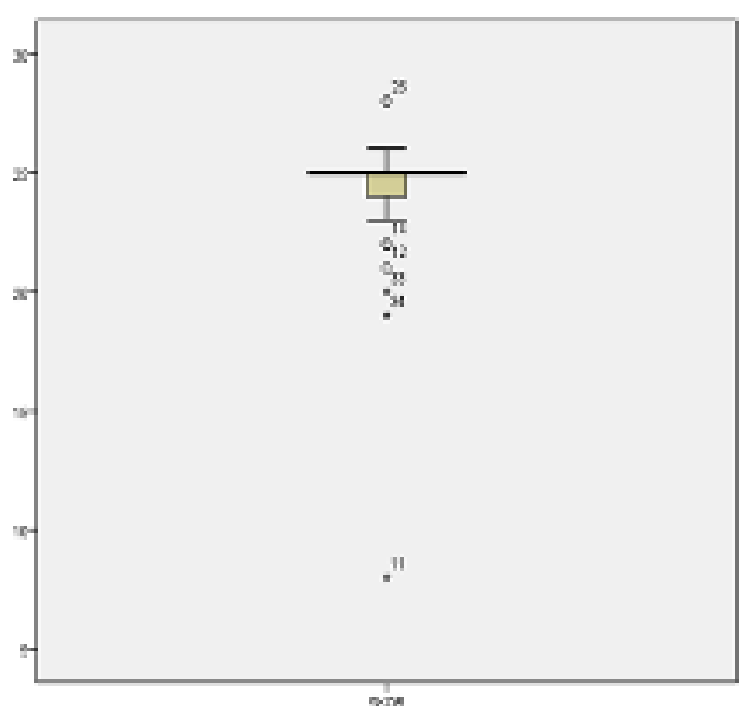

Gambar 2. Penyebaran data kelompok kontrol

Berdasarkan data di atas, untuk mengetahui apakah kemampuan numerik siswa kelas VII SMP Negeri 3 Gianyar yang mengikuti pembelajaran dengan model pembelajaran pair check lebih tinggi daripada siswa yang mengikuti pembelajaran konvensional, maka terlebih dahulu dilakukan pengujian terhadap normalitas dan homogenitas data.

Tabel 2. Rangkuman Hasil Uji Liliefors

\begin{tabular}{ccc}
\hline Kelompok & $\mathbf{L}_{\text {hitung }}$ & $\mathbf{L}_{\text {tabel }}$ \\
\hline Eksperimen & 0,1797 & 0,1437 \\
\hline Kontrol & 0,2139 & 0,1437 \\
\hline
\end{tabular}

Hasil pengujian normalitas skor kemampuan numerik siswa pada kelompok eksperimen diperoleh $\quad L_{\text {hitung }}=0,1797$ $>\mathrm{L}_{\text {tabel }}=0,1437$ (untuk $\mathrm{dk}=38$ pada taraf signifikansi $5 \%$ ), pada kelompok kontrol diperoleh $L_{\text {hitung }}=0,2139>L_{\text {tabel }}=0,1437$ (untuk $\mathrm{dk}=38$ pada taraf signifikansi $5 \%$ ), maka $\mathrm{H}_{0}$ ditolak yang berarti bahwa data dari dua kelompok tidak mengikuti sebaran normal.

Hasil uji homogenitas varians dari skor kemampuan numerik siswa diperoleh nilai $W=2,241<F_{\text {tabel }}=3,970$ (untuk $v_{1}=1$ dan $\mathrm{v}_{2}=74$ pada taraf signifikansi $5 \%$ ) yang berarti $\mathrm{H}_{0}$ diterima yang memberikan kesimpulan bahwa skor kemampuan numerik siswa memiliki varians yang homogen.
Pengujian normalitas menyatakan sebaran data tidak normal dan homogenitas sudah terpenuhi, maka dilanjutkan dengan pengujian hipotesis menggunakan uji-U Mann-Whitney.

Tabel 3. Rangkuman Hasil Uji U MannWhitney Kemampuan Numerik Siswa

\begin{tabular}{|c|c|c|}
\hline & \multicolumn{2}{|c|}{ Kelompok } \\
\hline & Eksperimen & Kontrol \\
\hline $\mathbf{n}$ & 38 & 38 \\
\hline $\begin{array}{l}\text { Rata-rata } \\
\text { peringkat }\end{array}$ & 43,62 & 33,38 \\
\hline $\mathbf{U}$ & \multicolumn{2}{|c|}{527.500} \\
\hline $\mathbf{Z}$ & \multicolumn{2}{|c|}{$-2,082$} \\
\hline$p$ value & \multicolumn{2}{|c|}{0,0188} \\
\hline
\end{tabular}

Hasil analisis didapatkan $p$ value $=0,0188<\alpha=0,05$ pada taraf signifikansi $5 \%$ yang berarti bahwa kemampuan numerik siswa yang dibelajarkan dengan model pembelajaran pair check lebih tinggi daripada kemampuan numerik siswa yang dibelajarkan dengan pembelajaran konvensional.

\section{Pembahasan}

Berdasarkan analisis data, kemampuan numerik siswa kelompok eksperimen lebih tinggi daripada kemampuan numerik siswa kelompok kontrol. Hal ini menunjukkan bahwa pembelajaran dengan menggunakan model pembelajaran pair check lebih efektif daripada pembelajaran secara konvensional. Hasil pengujian menunjukkan rata-rata skor kemampuan numerik siswa yang mengikuti pembelajaran dengan model pembelajaran pair check adalah 24,9737 sedangkan rata-rata skor kemampuan numerik siswa yang mengikuti model pembelajaran konvensional adalah 23,9737. Hal ini dikarenakan siswa dituntut untuk mampu memberikan penilaian sebagai coach sekaligus menjawab pertanyaan. Pertanyaan-pertanyaan atau tantangan selama pembelajaran dapat membangun interaksi, kerjasama dan siswa cenderung aktif dan kreatif dalam setiap proses pembelajaran di kelas. Setiap siswa akan memilik kesempatan untuk menyampaikan pendapatnya sendiri dan guru hanya sebagai pembimbing dalam pembelajaran di kelas. Model pembelajaran pair check selain 
meningkatkan kerja sama kelompok, siswa juga bertanggung jawab terhadap pekerjaan sendiri sehingga timbul kemandirian dan rasa percaya diri siswa dalam mengerjakan LKS.

Penelitian dilakukan selama sembilan kali pertemuan dengan materi ajar statistika. Pada setiap pertemuan siswa akan belajar secara berkelompok, untuk mendiskusikan beberapa permasalahn yang terdapat pada Lembar Kerja Siswa (LKS) yang diberikan oleh guru.

Pembelajaran dengan model pair check ini terdiri dari beberapa langkah yang diawali dengan pendahuluan, dimana guru melakukan apersepsi berkaitan dengan materi yang dibahas dan memberikan motivasi kepada siswa untuk mengetahui pentingnya mempelajari materi statistika. Kegiatan kedua adalah adalah kegiatan inti dengan menerapkan model pembelajaran pair check. Langkah pertama yaitu pairs work. Guru membagi siswa kedalam kelompok yang terdiri dari 4 siswa, dengan masing-masing kelompok tersebut dibagi lagi menjadi pasangan-pasangan yang disebut tim. Guru menjelaskan kepada siswa tentang pembelajaran pair check dan memberi kesempatan siswa menentukan siapa penyaji (pemecah masalah) yang bertugas mengerjakan/menyelesaikan masalah yang terdapat pada LKS atau menjadi coach (pelatih) yang bertugas membimbing pemecah masalah. Pada langkah ini, siswa dituntut untuk bertanggung jawab terhadap perannya masing-masing. Selaras dengan penelitian yang dilakukan Huda (2013) bahwa model pembelajaran pair check juga melatih tanggung jawab sosial siswa, kerja sama, dan kemampuan memberi penilaian.

Pada langkah coach check guru kemudian membimbing siswa melakukan demonstrasi untuk menyelesaikan kegiatan pada LKS dan memberikan tugas kelompok untuk menyelesaikan LKS dengan berdiskusi. Setelah siswa yang menjadi pemecah masalah selesai menjawab soal, pada langkah ini coach akan memeriksa pekerjaan penyaji. Pada tahapan ini, siswa yang berperan sebagai coach tidak hanya memahami soal yang dikerjakan penyaji, tapi mampu untuk memberikan penilaian dari pekerjaan yang dilakukan pasangannya yang bertugas sebagai pemecah masalah. Tahapan penilaian menuntut coach mengecek dan mengkritisi jawaban penyaji, menuntut coach berpikir logis dan melakukan penalaran atas jawaban penyaji. Oleh karena itu siswa dituntut untuk mempersiapkan diri sebelum proses pembelajaran dimulai. Pertanyaanpertanyaan selama proses pembelajaran dapat membangun interaksi, sehingga siswa tidak sungkan bertanya dengan temannya yang lebih mengerti. Setelah proses pemeriksaan jawaban penyaji, coach memberikan pujian (coach praises) apabila mereka telah menyepakati jawaban yang sama. Sehingga pada langkah selanjutnya pasangan akan bertukar peran.

Jika dalam satu kelompok sudah menyelesaikan LKS, maka guru meminta siswa menukarkan jawaban mereka dengan kelompok lain dan mengecek jawaban dari hasil diskusi kelompok lain. Jika semua pasangan dalam kelompok telah menyepakati jawaban yang sama, maka para anggota kelompok saling bersalaman. Namun ketika ada perbedaan, siswa dituntut untuk saling berbagi dalam kemampuan kognitifnya sehingga terjadi saling tukar pendapat untuk meningkatkan kemampuan berpikir siswa, yang sebelumnya tidak tahu menjadi paham, begitu juga jika terjadi kekeliruan dalam pengerjaan maka dengan mengamati pasangannya dapat membantu menemukan kebenaran jawaban. Interaksi yang terjadi antara siswa menjadikan siswa lebih aktif dalam proses pembelajaran. Terakhir guru memberikan penghargaan kelompok yang jawabannya benar. Dengan adanya keaktifan yang sudah ditunjukkan siswa dan dilatih dalam setiap pertemuan, semakin membantu siswa dalam mengembangkan kemampuannya. Hal ini dapat diamati dari proses pembelajaran dikelas. Dalam proses pembelajaran, tidak ada siswa yang tidak ikut berperan aktif, semua siswa terlibat dan berperan aktif dalam pembelajaran. Hal ini disebabkan karena semua siswa memiliki kesempatan yang sama dalam menjawab pertanyaan dan memberi penilaian. Siswa juga selalu menunjukkan bahwa mereka semakin termotivasi dalam belajar matematika.

Berbeda dengan hal diatas, pada awal pembelajaran siswa masih merasa kurang 
memahami peran mereka dalam mengerjakan LKS. Terlebih lagi ketika mereka harus bertukar peran yang menyebabkan kegaduhan sempat terjadi. Adanya batas waktu dalam menjawab pertanyaan pada pertemuan pertama menjadi kendala bagi siswa, karena siswa cenderung menawar-nawar waktu dalam menyelesaiakan pertanyaan dan beberapa siswa yang selesai dengan cepat. Tetapi pada pertemuan selanjutnya siswa sudah mulai terbiasa menjawab pertanyaan sehingga tidak diperlukan lagi membatasi waktu karena siswa menyelesaikan lebih banyak soal agar lebih unggul dari kelompok yang lainnya, yang tentunya siswa harus mempersiapkan diri sebelum pembelajaran di kelas dimulai. Tahap ini sangat membantu kemampuan numerik siswa dalam pembelajaran.

Sejalan dengan penelitian yang dilakukan oleh Edy Setiyo Utomo (2016), yang memberikan kesimpulan bahwa model pembelajaran pair check memberikan pengaruh yang efektif dalam meningkatkan hasil belajar matematika siswa daripada pembelajaran dengan model pembelajaran konvensional. Peningkatan hasil belajar matematika tidak terlepas dari kemampuan numerik siswa. Selain itu berdasarkan penelitian yang dilakukan oleh Sakinah Komara (2010) menyimpulkan bahwa ratarata hasil belajar matematika siswa yang diajarkan dengan menggunakan model pembelajaran pair check lebih tinggi daripada rata-rata hasil belajar matematika siswa yang diajarkan dengan pembelajaran konvensional. Hal ini terjadi karena model pembelajaran pair check menjadikan pemahaman siswa lebih berkembang karena siswa terlibat langsung (learning by doing) sehingga membuat proses pembelajaran lebih bermakna bagi siswa.

Terjadinya peningkatan hasil belajar matematika siswa tidak terlepas dari meningkatnya kemampuan numerik siswa. Seseorang dengan kemampuan numerik mempunyai kemampuan mengelola logika dan angka dengan aktivitas utama berpikir logis, berhitung, menyusun pola hubungan, dan memecahkan masalah. Suparlan (2009) mendefinisikan kemampuan numerik merupakan kemampuan menyelesaikan soal-soal matematika yang didalamnya termuat kemampuan melakukan pengerjaan-pengerjaan hitung dan proses berpikir logis dan sistematis. Dengan kemampuan numerik yang dimiliki tersebut dapat memudahkan siswa dalam memahami pelajaran. Dengan penguasaan materi yang dimiliki, seorang siswa mampu mendapatkan hasil belajar yang optimal. Dari beberapa uraian diatas, bisa disimpulkan bahwa model pembelajaran pair check memiliki keunggulan yaitu (1) siswa dilatih agar mampu bertanggung jawab terhadap pembelajaran mereka, (2) mengaktifkan semua siswa dalam pembelajaran, (3) mengeksplorasi kemampuan numerik siswa, (4) mengajak siswa terlibat langsung dalam memberikan penilaian dalam menjawab pertanyaanpertanyaan yang ada.

Berdasarkan perhitungan statistik yang telah dilakukan, menunjukkan bahwa model pembelajaran pair check membawa pengaruh positif dalam meningkatkan kemampuan numerik siswa. Hal ini memberikan implikasi bahwa model pembelajaran pair check dapat diterapkan dalam pembelajaran matematika sebagai upaya untuk meningkatkan kemampuan numerik siswa.

\section{SIMPULAN DAN SARAN \\ Simpulan}

Berdasarkan hasil analisis, uji hipotesis dan pembahasan yang telah diuraikan sebelumnya, dapat disimpulkan bahwa kemampuan numerik siswa yang dibelajarkan dengan model pembelajaran pair check pada kelas eksperimen lebih baik daripada kemampuan numerik siswa yang dibelajarkan dengan pembelajaran konvensional. Jadi dapat disimpulkan bahwa terdapat pengaruh positif dari model pembelajaran pair check terhadap kemampuan numerik siswa.

\section{Saran}

Berdasarkan hasil penelitian yang diperoleh, peneliti melalui tulisan ini mengajukan beberapa saran sebagai berikut.

1. Peneliti lain disarankan agar mengujicobakan pengaruh model 
pembelajaran ini pada aspek pembelajaran yang berbeda.

2. Karena keterbatasan biaya, waktu dan tenaga, penelitian ini dilakukan pada populasi yang terbatas, yaitu pada siswa kelas VII SMP Negeri 3 Gianyar. Peneliti menyarankan kepada peneliti lain yang tertarik untuk melakukan penelitian dengan model pembelajaran pair check agar meneliti terhadap jenjang kognitif yang lain dengan populasi yang lebih besar. Hal ini untuk mengetahui pengaruh model pembelajaran pair check dalam pembelajaran matematika secara lebih mendalam.

\section{DAFTAR PUSTAKA}

Danasasmita, Wawan. 2008. Model-Model Pembelajaran Alternative. Bandung: UPI.

Depdiknas. 2006. Peraturan Pemerintah RI No. 22 Tahun 2006 Tentang Standar Nasional Pendidikan. Jakarta: Cemerlang

Huda, Miftahul. 2014. Model-Model Pengajaran dan Pembelajaran. Yogyakarta: Pustaka Pelajar

Irawan, Ari. 2014. Pengaruh Kecerdasan Numerik dan Penguasaan Konsep Matematika Terhadap Kemampuan Berpikir Kritis Matematika. Jurnal Formatif, Volume 4 Nomor 1 (hlm. 46-55)

Jayantika, Trisna. 2013. Kontribusi Bakat Numerik, Kecerdasan Spasial, dan Kecerdasan Logis Matematis Terhadap Prestasi Belajar Matematika Siswa SD Negeri Di Kabupaten Buleleng. Tesis Program Pasca Sarjana Undiksha Singaraja.

Leoni, Agustin. 2008. Super Tes IQr. Tangerang: PT. Tangga Pustaka.

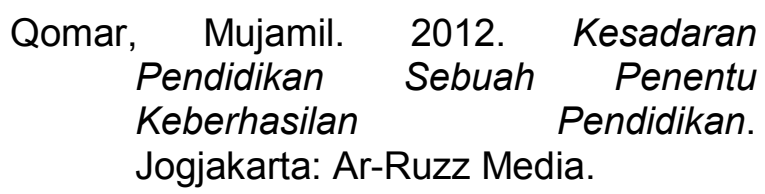

Sakinah, Komara. 2010. Pengaruh Model Pembelajaran Kooperatif Tipe Pairs check Terhadap Hasil Belajar Matematika Siswa. Skripsi Universitas Islam Negeri Syarif Hidayatullah.

Setiyo, Edy. 2016. Pengaruh Model Pembelajaran Kooperatif Pairs Check Terhadap Hasil Belajar Siswa. Seminar Nasional Matematika dan Pendidikan Matematika UNY.

Slameto. 2007. Belajar Dan Faktor-Faktor Yang Mempengaruhi. Jakarta: Rineka Cipta.

Slavin, Robert. 2010. Cooperative Learning: Applying Contact Theory In Desegrated Schools. Jurnal Of Social Issues. Vol 41 issues 3:45-62.

Sudijono, Anas. 2009. Pengantar Evaluasi Pendidikan. Jakarta: Rajawali Pers.

Suherman, Erman. dkk. 2003. Strategi Pembelajaran Matematika Kontemporer. Bandung: JICA.

Suparlan, Asup. 2009. Pengaruh Minat dan Kecerdasan Numerik Terhadap Prestasi Belajar Matematika Siswa. Jurnal Eduma, Volume 1 Nomor 2 (hlm. 129-136).

TIMSS (Trend in Mathematics and Science Study). 2011. Mathematics Framework. Jurnal TIMSS, Volume 1 (hlm.11-27).

Wirayana, Adi. 2015. "Pengaruh Model Pembelajaran Kooperatif Tipe Pairs check Berbantuan Kartu Soal Terhadap Hasil Belajar Matematika Siswa Kelas VIII Non Unggulan SMP Negeri 2 Singaraja". Skripsi UNDIKSHA Singaraja: tidak diterbitkan. 
Jurnal Pendidikan Matematika Undiksha, Volume X No 1, April 2019 e-ISNN:2599-2600; p-ISNN: 2613-9677

Yantiani, Ni Md, dkk. 2013. "Pembelajaran Kooperatif Pairs Check Berpengaruh Terhadap Hasil Belajar Materi Bangun Ruang dan Bangun Datar
Siswa Kelas IV Gugus IV Semarapura". Skripsi UNDIKSHA Singaraja: tidak diterbitkan 